\title{
Regional, national and international networks: the suitability of different competitive strategies for different geographic profiles
}

\author{
Marisa Cesário* and \\ Maria Teresa de Noronha Vaz
}

CIEO - Research Centre for Spatial and Organizational Dynamics, University of Algarve, Campus de Gambelas, FE, Edifício 9, 8005-139 Faro, Portugal

E-mail: mcesario@ualg.pt

E-mail:mtvaz@ualg.pt

*Corresponding author

\begin{abstract}
The aim of this paper is to conduct an exploratory investigation on the type of competitive strategies that are likely to be associated with different networking profiles. We focus our attention on response strategies related to investments and technological adjustments, and how they vary according to different spatial scales of firms' networks. We report the results of the application of a common questionnaire to a sample of 165 SMEs from labour-intensive sectors belonging to southern Europe. Using cluster analysis, the firms were grouped according to the use of regional, national and international geographic scales for supply, distribution and sales networks. For each group, response strategies were analysed. Our results allow us to observe that there is a relation between the capacity to improve the geographic scale of networking and the capacity to strategically react to changing market conditions.
\end{abstract}

Keywords: networking profiles; geographic scales; competitive strategies; manufacturing; small business.

Reference to this paper should be made as follows: M. Cesário and M.T. de Noronha Vaz (xxxx) 'Regional, national and international networks: the suitability of different competitive strategies for different geographic profiles', Int. J. Entrepreneurship and Small Business, Vol. X, No. Y, pp.000-000.

Biographical notes: Marisa Cesário holds a $\mathrm{PhD}$ in Economics and is an Assistant Professor at the University of Algarve. She is an Integrated Researcher at the Research Centre on Spatial and Organizational Dynamics (CIEO), since 2010. She teaches microeconomics and public economics at the undergraduate levels and regional economics and industrial development at Master levels. She has published scientific material related to economic geography, dealing with the agglomeration and co-agglomeration of industries and the economic specialisation of regions; and technological change dynamics and how they depend on different territorial attributes.

Maria Teresa de Noronha Vaz holds a PhD in Economics, and is a Professor of Economics of Innovation at the University of Algarve. She is the Director of the $\mathrm{PhD}$ programme in Innovation and Land Use Management and the President of the Research Centre on Spatial and Organizational Dynamics (CIEO), since 2007. At present, she is a visiting scholar and affiliated member 
of the Martin Prosperity Institute, University of Toronto. She coordinated several European, national and locally founded projects, co-edited ten international books about innovation and regional/rural development and published an extensive amount of scientific material related to regional economics, public policies and the use of instruments to implement innovation in lagging areas.

This paper is a revised and expanded version of a paper entitled 'Regional, national and international networks: the suitability of different competitive strategies for different geographic profiles' presented at 15th Uddevalla Symposium Faro, Portugal, 14-16 June 2012.

\section{Introduction}

The continuous capacity of firms to learn is seen by many scholars as the critical solution in order to avoid firms from becoming locked into obsolete technological and competitive trajectories. This is a very common tendency, particularly in peripheral areas and/or labour-intensive industries.

Networks are often seen as the channel to overcome the risk that firms may become rigid. By accessing other markets, assets and technologies, firms free themselves from their own limitations while following the technological trajectories of their competitors. Case-studies across Europe give empirical and theoretical perspectives on how firms benefit from external linkages with other firms along the value-chain (Alvarez et al., 2009; Arndt and Sternberg, 2000; Cantner et al., 2010; Mazzola et al., 2009).

Our main purpose in this paper is to empirically analyse the relation between the capacity of firms to strategically react to changing market conditions and their networking propensities.

We emphasise the interconnected nature of those aptitudes, arguing the dependence between each other. In addition to confirming the positive effects of the ability to network on company performance, we also confirm that there are certain 'enablers' necessary for successful cooperation (Hanna and Walsh, 2002, 2008). Firms that do not cooperate, and that do not formally or informally exchange knowledge, limit their long-term knowledge-base and, ultimately, reduce their ability to enter into exchange relationships (Pittaway et al., 2004).

More specifically, regarding product and process innovation, positive associations were found in cooperation with customers, suppliers, the public sector, and universities (Freel and Harrison, 2006); however, in some cases, the effects are not as direct because there are sectoral and regional influences in the efficiency with which such networking inputs are translated into innovative outputs (Love and Roper, 2001).

Our empirical analysis is based on the application of a common questionnaire to a sample of 165 SMEs from the textiles, clothes and leather (TCL) sectors belonging to a group of Southern European areas: North (Portugal), Valencia (Spain), Macedonia (Greece) and South Italy (Italy). We report data on the use of supplier-distribution-sales networks at the local/regional, national, European and international levels. 
Using cluster methods, we aim to identify the different geographic networking profiles within the sample. For each profile, competitive strategies related with investments and new technologies are analysed so statistical dependences between these strategies and group membership can be tested. We state that an interdependent relationship occurs between the networking and strategic capacities of firms.

\section{Small firm networking}

\subsection{Network scaling-up}

Networks may be distinguished from one another by reference to who qualifies for entry and who is excluded from membership. With scares resources and limited opportunities for trade, the sharing of a common identity is an efficient mechanism for excluding others from access to those resources (Clark, 2004).

The simplest definitions of networks suggest the involvement of economic agents who engage in repeated transactions. This repetition is a means of sharing values and expectations about proper behaviour. Morgan (1996) defends the business networks as the most effective and credible way for knowledge acquisition. Similarly, Gulati et al. (2000) state that a firm's network can create inimitable and non-substitutable value just as any inimitable resource by itself. Besides the access to resources and skills, networks of interaction also improve firms' response capacities to changing competitive circumstances, allowing the reduction of risks, information and transaction costs and allowing the development of trust and social cohesion, hence facilitating problem-solving (Hotz-Hart, 2000).

Further to the more formal nature of transactions involved in a firm network, the definition of networking often embraces more informal collaborative linkages. The term 'untraded interdependencies' was used by Storper (1995) to define those relationships that extend beyond traditional customer/supplier links and embrace interdependencies that are untraded and include conventions, common languages and rules.

One way or another, networks have different geographical nodes. Although much of the literature on networks refers to issues such as embeddedness (Granovetter, 1985) and path dependence (Nelson and Winter, 1982; Dosi et al., 1988; Arthur, 1994; Dosi, 1997) that implicitly mean the efficiency of local linkages, our focus is upon the different spatial scale of firms' supply and distribution linkages, arguing that network configuration may be associated with different adjustment strategies.

Literature recognises that networking is vital for firm performance, but in particular for TCL; we proved elsewhere (Cesário and de Noronha Vaz, 2012) that the contacts with international suppliers, for instance, are one of the most important sources of technological knowledge. As the drivers of globalisation are removing barriers which traditionally segmented the competitive environments of small and large firms, firms of all sizes are joining international networks (Dana, 2001). While some sectors often need to internationalise their activities, especially sales, at a very early stage of their development because of limited domestic markets (Cantwell, 1995; Keeble et al., 1998), others do it in search of technical advances. Nachum and Keeble (2003) argue that firms need to identify a successful balance between localised sources of interaction and those in wider geographic areas, and to establish linkages at those different geographic scales in order for them to compete successfully. 
Even when industrial districts are strongly and successfully embedded, international sourcing is hardly prevented as traditional manufacturing industries become more heavily involved in the global arena. The Spanish home-textiles (Pla-Barber and Puig, 2009) and the Italian footwear and apparel industries (Camuffo et al., 2007) are good examples.

In manufacturing sectors, as already stated, networking activities are primarily based on vertical relationships such as customer, manufacturer supplier and producer service provider networks, rather than on horizontal linkages such as producer networks and industry-university linkages (Fischer and Varga, 2002), and firms tend to rely on sources of technology from national and, especially, international sources.

In this paper we are particularly interested in the scaling-up of those forward and backward linkages and how different geographic profiles are associated with different strategic responses.

\subsection{The importance of networking in TCL sectors}

We argue that networking strategies are mandatory in two ways in TCL industries because:

a These sectors belong to the so-called supplier-dominated industries, where innovative opportunities are primarily a process of diffusion of best-practice along the value-chain (Cesário and de Noronha Vaz, 2012).

b Both horizontal and vertical links allow firms to create critical mass and exploit standardisation opportunities that should lead to reductions in costs, enhancement of quality and reduction of technological and commercial risks (Cesário and de Noronha Vaz, 2011).

Empirical studies across Europe corroborate these arguments. For example, the importance of sourcing and subcontracting was observed by Smith et al. (2008) when assessing the capacity of these strategies to sustain European clothing production networks, despite the 'spectre of China'. In fact, the global garment industry is currently being reshaped in dramatic ways through processes of trade liberalisation, delocalisation and inter-firm and interregional competition. Although the higher labour costs of European firms can induce further rounds of de-localisation of garment production towards low-cost production locations, such as China and India, the authors argue that that does not necessarily mean the end to garment production in higher European factor-cost locations if the right supply, distribution and sales networks are developed.

This is truer when considering the fashion industry, where the consistent use of outsourcing means that material production is constantly on the move to low-cost locations (Hauge et al., 2009). For firms in European high-cost countries, the creation of value and profitability commonly rests not only on the ability to produce innovative design and brand value, but also on efficient marketing channels, logistics and distribution. 
Although we recognise the importance of the social facet of networking (one that is harder to measure), our arguments emphasise the market relations in supply, distribution and sales networks. In this paper we consider that a market transaction constitutes a network activity, based on the idea that, ultimately, all market transactions appear as the outcome of previous social connections along the value-chain (horizontally and vertically). According to Staber (2011), 'marketless' conceptions of social networks in clusters are overstated and need to be balanced with a stronger concern for the role of competition in the social embeddedness of small firms. Whatever the contents and motivating factors for networking, firms always seek the benefits for their client and resource base, while they only prudently collaborate with competitors (Shaw, 2006).

\section{Research design}

\subsection{Questions addressed}

The aim of this paper is to conduct an exploratory investigation on the type of competitive strategies that are likely to be associated with different networking profiles.

We focus our attention on response strategies related to investments made and technologies adopted, and how they vary according to different spatial scales of firms' networks.

\subsection{Sampling}

Empirically, the analysis is based on the application of a common questionnaire to a sample of 165 SMEs from the TCL sectors (Table 1) belonging to the following Southern European areas: North (Portugal), Valencia (Spain), Macedonia (Greece), and South Italy (Italy). Appendix 1 gives the sampling procedures.

Table 1 Sample distribution by focus area and sector

\begin{tabular}{lccc}
\hline & Footwear and leather products & Textiles and clothes & Total \\
\hline North, Portugal (PT) & 14 & 52 & 66 \\
Macedonia, Greece (GR) & 14 & 34 & 48 \\
South Italy (IT) & - & 24 & 24 \\
Valencia, Spain (SP) & 15 & 12 & 27 \\
Total & 43 & 122 & 165 \\
\hline
\end{tabular}

These areas are composed of one or more NUTS II regions and were selected because of their economic vulnerability established in three common features:

a these areas are lagging behind the EU-27 average in terms of gross domestic product (GDP) per capita

b their heavy industrial tissues are mainly composed of labour-intensive activities, the ones most affected by low-wage competition

c their peripheral geographic location constitutes an economic restraint (Cesário and de Noronha Vaz, 2012). 


\subsection{Data and methodology}

Agglomerative hierarchical clustering was used to find similar groups of firms according to the use of different geographical scales (regional, national and international) for supply, distribution and sales networks. The distances between firms were calculated using the square Euclidean distance. The distance between two groups was defined as the distance between their average values (the centroids).

In order to draw the different networking profiles, the authors used the information provided by firms about the geographical and functional origin and destination of inputs to production and outputs of production. Database variables are presented in Appendix 2.

In order to detect if the adjustment strategies of firms vary across the different networking profiles, the response variables (in Appendix 3) were cross tabulated with the group membership of each firm.

Adjustment strategies were separated in investment strategies, specifically regarding the nature of investment made, and technological strategies, in what concerns the type of technologies adopted.

The chi-square statistic was used to test the hypothesis that the competitive strategies of firms are independent from group membership. A low significance value $(p<0.05)$ indicates that strategies are significantly different across the different networking profiles. The analysis of the Cramer's V statistic is used to give additional information on the strength of that variation.

\section{Results}

This section will present the results of the clustering exercise as well as the results of the chi-square statistics.

\subsection{Networking profiles}

The cluster analysis allows the identification of different networking profiles. This section will look to the results of that statistical procedure, combining that information with the main descriptive statistics for each group, in order to provide a better characterisation of each cluster.

The 165 regions were grouped as described in Table 2 (from the initial group of 165 firms, 15 were excluded because of missing values). The networking profile of each group is easily depicted from Figures 1 to 3 .

Group 1 is composed of 73 firms with a regional/national network profile. This is the less internationalised group, which mostly develops links with local/regional or national suppliers and customers. Firms in this group are generally smaller than firms in the other groups, in terms of number of employees and value of sales. This group will be labelled as the one with a regionally-based networking profile.

Group 2 is composed of 27 firms with a strong international orientation. This group develops strong linkages with European suppliers, distributors and customers, but weaker linkages inside country borders. Firms in this group mostly present higher value of sales due to exports. This group will be labelled as the one with an internationally-based networking profile. 
Group 3 is composed of 50 firms with a wider market position, both national and in Europe. Firms in this group are generally older and higher-scaled in terms of employees, but not in terms of the value of sales, because a substantial part of sales is absorbed by the national market, at lower prices than exports. This group will be labelled as the one with a nationally and internationally-based networking profile.

Table 2 Descriptive statistics

\begin{tabular}{llcccc}
\hline & & Group 1 & Group 2 & Group 3 & Total \\
& & $N=73$ & $N=27$ & $N=50$ & $N=150$ \\
\hline Employment & $<=14$ & $60 \%$ & $19 \%$ & $18 \%$ & $38 \%$ \\
& $15-49$ & $28 \%$ & $44 \%$ & $40 \%$ & $35 \%$ \\
& $50+$ & $13 \%$ & $37 \%$ & $42 \%$ & $27 \%$ \\
Total & & $100 \%$ & $100 \%$ & $100 \%$ & $100 \%$ \\
\hline Sales (euros) & $<=1,600,000$ & $49 \%$ & $21 \%$ & $29 \%$ & $37 \%$ \\
& $1,600,001-12,500,000$ & $19 \%$ & $25 \%$ & $42 \%$ & $28 \%$ \\
& $12,500,001+$ & $32 \%$ & $54 \%$ & $29 \%$ & $35 \%$ \\
Total & & $100 \%$ & $100 \%$ & $100 \%$ & $100 \%$ \\
\hline Year of & $<=1979$ & $26 \%$ & $33 \%$ & $39 \%$ & $32 \%$ \\
establishment & $1980-1989$ & $36 \%$ & $37 \%$ & $29 \%$ & $34 \%$ \\
& $1990+$ & $38 \%$ & $30 \%$ & $33 \%$ & $35 \%$ \\
Total & & $100 \%$ & $100 \%$ & $100 \%$ & $100 \%$ \\
\hline
\end{tabular}

Figure 1 The use of supply networks by group

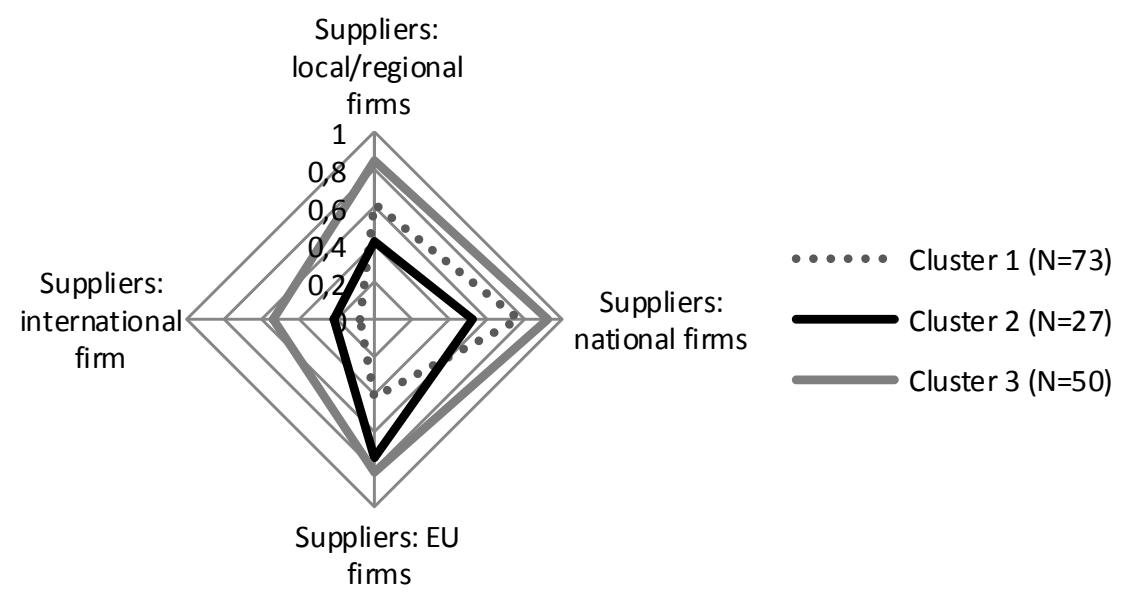


Figure 2 The use of distribution networks by group

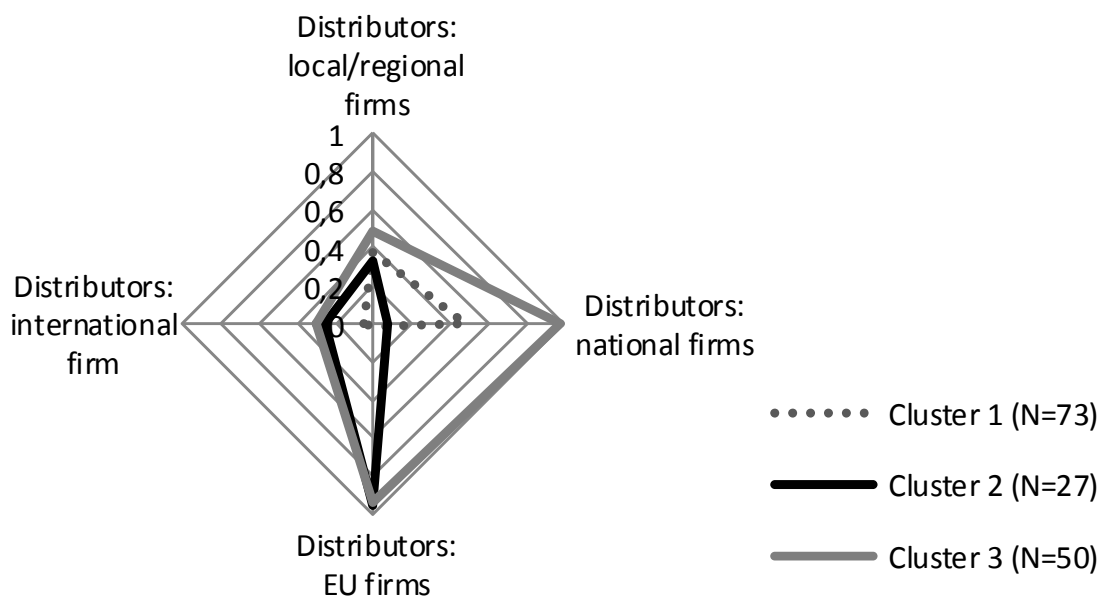

Figure 3 The use of sales networks by group

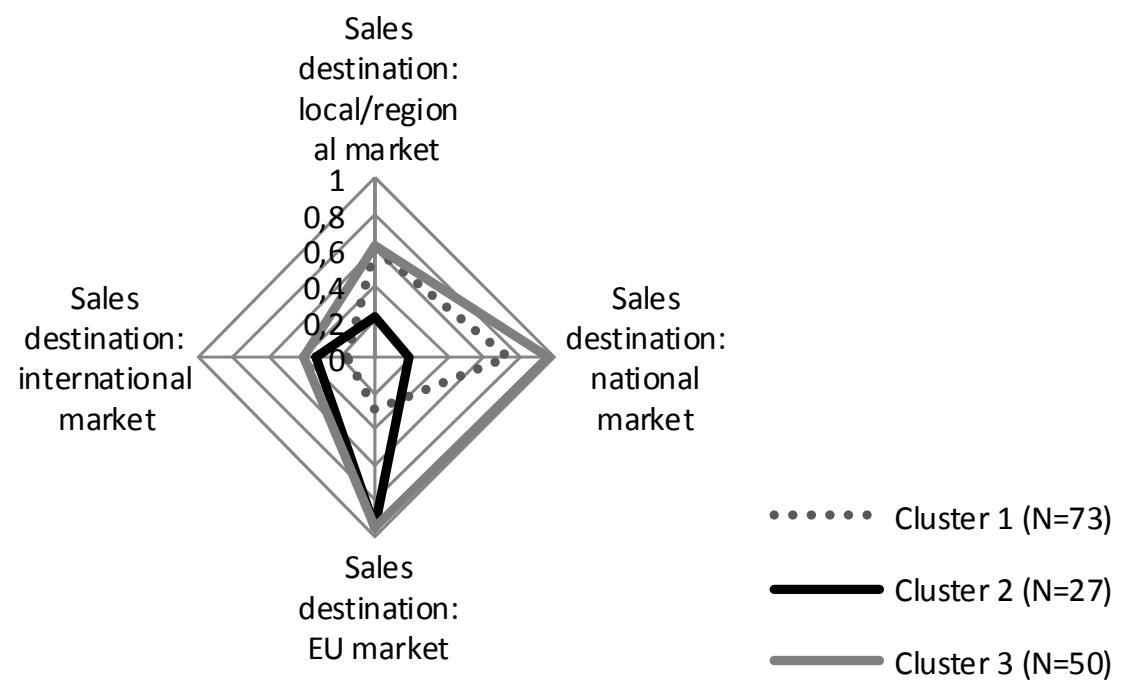

\subsection{Investment and technology strategies}

This section gives the results of the chi-square statistics used to examine if the response strategies considered in this study are related with the different networking profiles.

Tables 3 and 4 list the chi-square, the Cramer's V and their significances. The chi-square results allow identifying the response variables that are not independent from the group membership. The observation of Cramer's V allows determining the strengths of the association, when present. 
The rule of thumb that $80 \%$ of cells should have an expected count of five or more, and no cells should have a zero expected count, was used as reference.

When interpreting the following results, attention should be paid to the fact that significant variables are identified when they are determinant to distinguish between the groups. When a variable is not indicated as significant, that does not mean that that variable is not important for the firms themselves. It means that it is not important to distinguish between the profiles.

\subsubsection{Investment strategies}

From the list of variables related with investment strategies, there are three with significantly different results across the three groups of firms (Table 3). A $\alpha=0.1$ was exceptionally considered in this case given the importance of analysing the two variables with a significance level slightly above five percent. In testing the hypothesis that investment strategies vary within different networking profiles, the null hypotheses were rejected for the investment in information technology $(p=0.001)$, the investment in the purchase of patents and licensing $(p=0.084)$ and the investment in the development of existing products $(p=0.064)$. The most distinguishing variable across the three groups was the investment in information technology $(V=0.303)$.

Table 3 Chi square results for investment strategies

\begin{tabular}{lccc}
\hline Variable & $\chi^{2}$ & $V$ & Sig. \\
\hline \multicolumn{1}{c}{ H0: Investment strategies are independent from group membership } \\
\hline Firm invested in: new plant and equipment? & 3.454 & 0.152 & 0.178 \\
Firm invested in: information technology? & 13.730 & 0.303 & 0.001 \\
Firm invested in: the purchase of patents and licensing? & 4.964 & 0.182 & 0.084 \\
Firm invested in: the development of existing products? & 5.491 & 0.191 & 0.064 \\
Firm invested in: the development of new products? & 1.874 & 0.112 & 0.391 \\
\hline
\end{tabular}

From Figure 4 we observe the following:

- The third group presents higher incidences in terms of investments in IT and in the development of existing products. This group is composed of older and bigger firms, with a higher network implantation, both national and international.

- The internationally-based networkers present the higher incidence of investments in the purchase of patents and licensing. This is a distinguishing feature of this export-oriented group. These types of investments are generally associated with breakthrough innovations, which can explain the higher valued sales that characterise this group.

- Although not very expressive, the regionally-based networkers distinguish from the international ones as they present a higher incidence of investments in the development of existing products. These are, essentially, smaller and regionalised firms. 
Figure 4 Investment strategies by networking profile

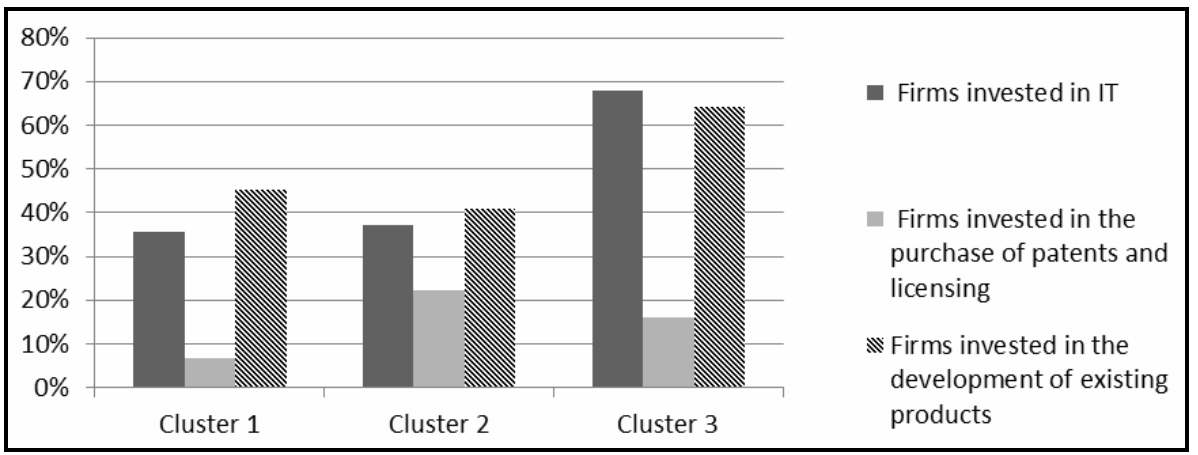

\subsubsection{Technological strategies}

In what concerns the variables related with technological strategies, there are three with significantly different results ( $\alpha=0.05$ ) across the three groups of firms (Table 4$)$.

In testing the research hypothesis that technological strategies vary within different networking profiles, the null hypotheses were rejected for the adoption of new technologies related with: production processes $(p=0.006)$, product design $(p=0.011)$ and marketing tools $(p=0.000)$. The most distinguishing variable across the three groups was the adoption of new technologies related to marketing technology ( $\mathrm{V}=0.350)$.

Table 4 Chi square results for technological strategies

\begin{tabular}{lccc}
\hline Variable & $\chi^{2}$ & $V$ & Sig. \\
\hline \multicolumn{1}{c}{ H0: Technological strategies are independent from group membership } \\
\hline Technologies adopted: inventory control & 2.226 & 0.122 & 0.329 \\
Technologies adopted: production process technology & 10.082 & 0.259 & 0.006 \\
Technologies adopted: product design technology & 9.059 & 0.246 & 0.011 \\
Technologies adopted: marketing technology & 18.217 & 0.350 & 0.000 \\
Technologies adopted: B to B electronic networks & 3.177 & 0.146 & 0.204 \\
\hline
\end{tabular}

From Figure 5 we conclude that:

- A main distinguishing feature between regional and international networkers regards the adoption of production process and product design technologies (such as CAD and CAM). The use of such instruments is marginal in the small domestic firms from the first group.

- $\quad$ Regarding the technological variables related with marketing tools, the incidence of investments in such technologies is much higher in cluster 3, which has a higher network implantation, with a national and international nature. This group shows high occurrences on the three types of technologies adopted but, differently from the export-oriented group, cluster 3 favours marketing instruments. 
Figure 5 Technological strategies by networking profile

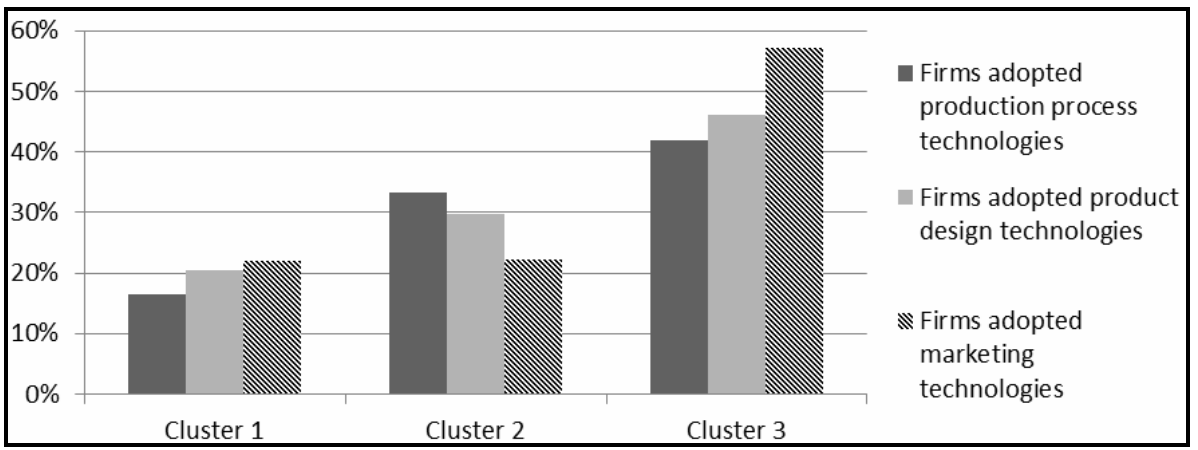

\subsection{Discussion of results}

The following table summarises the several findings in order to facilitate the discussion.

\begin{tabular}{|c|c|c|c|}
\hline Cluster & $\begin{array}{c}1 \\
\text { Regionally-based } \\
\text { networking profile }\end{array}$ & $\begin{array}{c}2 \\
\text { Internationally-based } \\
\text { networking profile. }\end{array}$ & $\begin{array}{c}3 \\
\text { Nationally and } \\
\text { internationally-based } \\
\text { networking profile }\end{array}$ \\
\hline Main feature & Smaller firms & Higher value of sales & $\begin{array}{l}\text { Older and bigger } \\
\text { firms }\end{array}$ \\
\hline $\begin{array}{l}\text { Main distinguishing } \\
\text { response strategies }\end{array}$ & $\begin{array}{l}\text { Higher incidence of } \\
\text { investments in the } \\
\text { development of } \\
\text { existing products } \\
\text { than cluster 2; } \\
\text { marginal occurrence } \\
\text { of adoption of } \\
\text { production process } \\
\text { and product design } \\
\text { technologies }\end{array}$ & $\begin{array}{l}\text { Higher incidence of } \\
\text { investments in the } \\
\text { purchase of patents } \\
\text { and licensing than the } \\
\text { others; favouring the } \\
\text { adoption of } \\
\text { production process } \\
\text { and product design } \\
\text { technologies }\end{array}$ & $\begin{array}{l}\text { Higher occurrences } \\
\text { of investments in IT } \\
\text { and in the } \\
\text { development of } \\
\text { existing products } \\
\text { than the others; } \\
\text { higher occurrences of } \\
\text { adoption of new } \\
\text { technologies, but } \\
\text { favouring marketing } \\
\text { instruments }\end{array}$ \\
\hline
\end{tabular}

As expected, we observe differences among the three groups regarding not only the type of firms (age and size) but also the nature of investments made and type of new technologies adopted recently.

The results allow the identification of a major group of regionally-based networkers, essentially smaller firms, that are distinguished from the others by their weaker aptitude to technological adjustments.

It is also possible to observe that the third group, which is characterised by older and bigger firms, with a national and international network implantation, differs from the export-oriented group, as firms in cluster 3 invest more in the acquisition of new IT technologies and in the development of existing products, but invest less in the acquisition of patents and licenses. 
Given these two different investment orientations, we can discuss the motivations and the implications of the internationalisation processes that both groups accomplish.

The internationalisation processes, especially regarding sales, are often developed because of limited domestic markets. The aim, in those cases, is to up-hold market share and to explore scale economies (quantity production). However, in the specific case of the export-oriented group identified in this study, this strategy seems to be associated with an innovative behaviour. In this case, the network scaling-up, more than simply being associated with market enlargement, reveals a preoccupation with added valued and quality production.

\section{Conclusions}

The aim of this paper was to conduct an exploratory investigation on the type of competitive strategies that are likely to be associated with different networking geographic scales.

Our focus is upon the different geographic levels of sales, supply and distribution linkages and how they are related with different investment and technological adjustments.

We base our evidence upon a comprehensive, cross-country database of surveyed firms, developed using a common analytical framework. This is a main contribution of the present paper, as the study of competitive strategies is normally based on case studies.

From the observation of our sample of TCL firms from Southern Europe, it was possible to identify three different groups with distinguished geographic networking profiles. For each one of them, investment and technological adjustment strategies were analysed.

One of the profiles identified was the nationally and internationally-based networkers, a group that, besides a high level of internationalisation, is also embedded in local/national networks (a result also achieved by Keeble et al., 1998). Another profile identified was the internationally-based networkers, a group with a strong export orientation, with higher concerns with quality and innovation, reflected in the type of investments made (patents and licensing) and in the higher valued sales. This group presents good capability for international connections, while paying less attention to national contacts. Similar to Freel (2003), we found that export propensity is positively associated with innovative behaviours at a higher spatial level.

Finally, it was possible to identify a major group of regionally-based networkers, essentially smaller firms, with few concerns with innovation and new technologies.

Our results allow us to observe that investment and technological adjustment strategies vary across the three groups, indicating that there is a relation between the capacity to improve the geographic scale of networking and the capacity to strategically react to market-changing conditions. Similar to Clark (2004), it is shown that some types of competitive responses are associated with a process of scaling-up networks rather than remaining loyal to local linkages. 
While the related literature confirms the advantages of networking for the competitiveness of firms, we conclude that not all firms have the ability to develop international contacts.

The exploitation of marketing networks depends heavily on the openness towards new opportunities which, in turn, depends on the knowledge stock of firms (Cohen and Levinthal, 1990) and on the empowerment of employees to pursue it (Lechner and Dowling, 2003). At the end, the resource base of firms is both an input for and an output of networking activity, and that can be either a vicious or a virtuous cycle.

\section{Acknowledgements}

This paper has been partially supported by the Portuguese Foundation for Science and Technology (FCT).

\section{References}

Alvarez, I., Marin, R. and Fonfria, A. (2009) 'The role of networking in the competitiveness of firms', Technological Forecasting and Social Change, Vol. 76, No. 3, pp.410-421.

Arndt, O. and Sternberg, R. (2000) 'Do manufacturing firms profit from intraregional innovation linkages? An empirical based answer', European Planning Studies, Vol. 8, No. 4, pp.465-485.

Arthur, W.B. (1994) Increasing Returns and Path Dependence in the Economy, University of Michigan Press, Ann Arbour.

Camuffo, A., Furlan, A., Romano, P. and Vinelli, A. (2007) 'Routes towards supplier and production network internationalisation’, International Journal of Operations \& Production Management, Vol. 27, Nos. 3-4, pp.371-387.

Cantner, U., Conti, E. and Meder, A. (2010) 'Networks and innovation: the role of social assets in explaining firms’ innovative capacity’, European Planning Studies, Vol. 18, No. 12, pp.1937-1956.

Cantwell, J. (1995) 'The globalization of technology - what remains of the product cycle model', Cambridge Journal of Economics, Vol. 19, No. 1, pp.155-174.

Cesário, M. and de Noronha Vaz, M.T. (2011) 'The effects of globalisation on the performance of labour-intensive industries from southern Europe: the role of localised capabilities', International Journal of Economics and Management Sciences, Vol. 1, No. 4, pp.53-63.

Cesário, M. and de Noronha Vaz, M.T. (2012) 'Technological adjustments in textile, clothes and leather industries: an alternative pathway for competitiveness', in C. Karlsson, B. Johansson and R. Stough (Eds.): Entrepreneurship, Social Capital and Governance, pp. 325-357, Edward Elgar Publishing.

Clark, G.P., Palaskas, T., Tracey, P. and Tsampra, M. (2004) 'Market revenue and the scope and scale of SME networks in Europe's vulnerable regions', Environment and Planning A, Vol. 36, No. 7, pp.1305-1326.

Cohen, W.M. and Levinthal, D.A. (1989) 'Innovation and learning - the 2 faces of R-and-D', Economic Journal, Vol. 99, No. 397, pp.569-596.

Cohen, W.M. and Levinthal, D.A. (1990) 'Absorptive-capacity - a new perspective on learning and innovation', Administrative Science Quarterly, Vol. 35, No. 1, pp.128-152.

Dana, L.P. (2001) 'Networks, internationalization \& policy’, Small Business Economics, Vol. 16, No. 2, pp.57-62. 
Dosi, G. (1997) 'Opportunities, incentives and the collective patterns of technological change', The Economic Journal, Vol. 107, No. 444, pp.1530-1547.

Dosi, G., Freeman, C., Nelson, R., Silverberg, G. and Soete, L. (1988) Technical Change and Economic Theory, Pinter Publishers, London.

Fischer, M.M. and Varga, A. (2002) 'Technological innovation and interfirm cooperation: an exploratory analysis using survey data from manufacturing firms in the metropolitan region of Vienna', International Journal of Technology Management, Vol. 24, Nos. 7-8, pp.724-742.

Freel, M.S. (2003) 'Sectoral patterns of small firm innovation, networking and proximity', Research Policy, Vol. 32, No. 5, pp.751-770.

Freel, M.S. and Harrison, R.T. (2006) 'Innovation and cooperation in the small firm sector: evidence from 'Northern Britain’’, Regional Studies, Vol. 40, No. 4, pp.289-305.

Granovetter, M. (1985) 'Economic action and social structure: the problem of embeddedness', American Journal of Sociology, Vol. 91, No. 3, pp.481-510.

Gulati, R., Nohria, N. and Zaheer, A. (2000) 'Strategic networks', Strategic Management Journal, Vol. 21, No. 3, pp.203-215.

Hanna, V. and Walsh, K. (2002) ‘Small firm networks: a successful approach to innovation?’, $R \& D$ Management, Vol. 32, No. 3, pp.201-207.

Hanna, V. and Walsh, K. (2008) 'Interfirm cooperation among small manufacturing firms', International Small Business Journal, Vol. 26, No. 3, pp.299-321.

Hauge, A., Malmberg, A. and Power, D. (2009) 'The spaces and places of Swedish fashion', European Planning Studies, Vol. 17, No. 4, pp.529-547.

Hotz-Hart, B. (2000) 'Innovation networks, regions and globalisation', in G.P. Clark, M. Feldman and M. Gertler (Eds.): The Oxford Handbook of Economic Geography, pp.432-450, Oxford University Press.

Keeble, D., Lawson, C., Smith, H.L., Moore, B. and Wilkinson, F. (1998) 'Internationalisation processes, networking and local embeddedness in technology-intensive small firms', Small Business Economics, Vol. 11, No. 4, pp.327-342.

Lechner, C. and Dowling, M. (2003) 'Firm networks: external relationships as sources for the growth and competitiveness of entrepreneurial firms', Entrepreneurship and Regional Development, Vol. 15, No. 1, pp.1-26.

Love, J.H. and Roper, S. (2001) 'Location and network effects on innovation success: evidence for UK, German and Irish manufacturing plants’, Research Policy, Vol. 30, No. 4, pp.643-661.

Mazzola, E., Bruccoleri, M. and Perrone, G. (2009) 'A strategic framework for firm networks in manufacturing industry: an empirical survey’, Cirp Annals-Manufacturing Technology, Vol. 58, No. 1, pp.387-390.

Morgan, K. (1996) 'L’apprentissage par l'interaction : réseaux d'entreprises et services d’appui aux entreprises', in OCDE (Ed.): Réseaux d'entreprises et développement local, pp.59-73.

Nachum, L. and Keeble, D. (2003) 'Neo-Marshallian clusters and global networks - the linkages of media firms in Central London', Long Range Planning, Vol. 36, No. 5, pp.459-480.

Nelson, R. and Winter, G. (1982) An Evolutionary Theory of Economic Change, Harvard University Press, Cambridge MA.

Pittaway, L., Robertson, M., Munir, K., Denyer, D. and Neely, A. (2004) 'Networking and innovation: a systematic review of the evidence', International Journal of Management Reviews, Vol. 5-6, Nos. 3-4, pp.137-168.

Pla-Barber, J. and Puig, F. (2009) 'Is the influence of the industrial district on international activities being eroded by globalization? Evidence from a traditional manufacturing industry', International Business Review, Vol. 18, No. 5, pp.435-445. 
Rosenberg, N. and Frischtak, C.R. (1986) 'Technological innovation and long waves', in C. Freeman (Ed.), Design, Innovations and Long Cycles in Economic Development, pp.526, Frances Pinter, London.

Shaw, E. (2006) 'Small firm networking - an insight into contents and motivating factors', International Small Business Journal, Vol. 24, No. 1, pp.5-29.

Smith, A., Pickles, J., Bucek, M., Begg, R. and Roukova, P. (2008) 'Reconfiguring 'post-socialist' regions: cross-border networks and regional competition in the Slovak and Ukrainian clothing industry’, Global Networks - A Journal of Transnational Affairs, Vol. 8, No. 3, pp.281-307.

Staber, U. (2011) 'Partners forever? An empirical study of relational ties in two small-firm clusters’, Urban Studies, Vol. 48, No. 2, pp.235-252.

Storper, M. (1995) 'The resurgence of regional economies, ten years later: the region as a nexus of untraded interdependencies', European Urban and Regional Studies, Vol. 2, No. 3, pp.191-221.

Teece, D.J., Pisano, G. and Shuen, A. (1997) 'Dynamic capabilities and strategic management', Strategic Management Journal, Vol. 18, No. 7, pp.509-533.

Vicente P., Reis, E. and Ferrão, F. (1996) Sondagens - a amostragem como factor decisivo de qualidade, Edições Sílabo.

\section{Appendix 1}

\section{Sampling procedures}

The questionnaire used in the present research was designed, tested and applied in the scope of the EU FP5 Project RASTEI - Regional Adjustment Strategies to Technological Change in the Context of European Integration - HPSE-1999-00035.

This project aimed to study how local adjustment strategies designed to enhance productivity utilising technological change in labour-intensive industries has affected, and will affect in the future, European non-metropolitan regions in terms of their employment potential.

The results for the Greek, Italian and Spanish firms were generously provided by the project coordinator for the present research. The same questionnaire was applied to the Portuguese sample firms during 2005.

Using common questions and an agreed coding system, the dataset allows for the pooling of data by question across a group of European southern regions.

It should be recognised that the results of the present research are dependent, certainly, upon the integrity of the survey instrument, the sampling procedures and the collection of the data in each country, as in every multi-team cross-country research. In the present research, the author assumes the responsibility for the Portuguese questionnaire application. Similar sampling procedures were applied by the other teams.

\section{Sampling exercise for the Portuguese region}

The total number of 5,916 small and medium sized firms ( $<250$ employees) from CAE 17, 18 and 19 from Portugal North Region were considered as the target population. The data source is the Ficheiro das Unidades Estatísticas (FUE) from INE - Instituto Nacional de Estatística. 
The sample was randomly selected from the firms in the target population. The distribution among different regions and sectors was done proportionally.

A total number of 722 questionnaires were distributed by RSF post during a five-month period, followed by 217 phone contacts in order to supply complementary information and increase the final rate of answers. Finally, it was possible to come up with a final sample of 66 respondent firms, corresponding to a final answer rate of $18.3 \%$ from the initial, planned sample $(n=361)$. As mentioned by Vicente et al. (1996), the representativity of a sample is not a matter of its dimension; rather, it is a matter of whether or not the non-respondents' answers differ from the respondents' ones. Since it is expected that the non-answers are mainly due to the entrepreneurs' lack of availability and awareness regarding the cooperation in these sorts of research initiatives, it is assumed that the non-respondents' opinions do not bias the representativity of the final sample.

\section{Appendix 2}

Description of database variables for networking profile

\begin{tabular}{ll}
\hline Description & Codification \\
\hline Supply, distribution and customers networks & \\
Suppliers: associated local firms & $1=$ yes; $0=$ no \\
Suppliers: other local/regional firms & $1=$ yes; $0=$ no \\
Suppliers: national firms & $1=$ yes; $0=$ no \\
Suppliers: EU firms & $1=$ yes; $0=$ no \\
Suppliers: international firms & $1=$ yes; $0=$ no \\
Distributors: associated local firms & $1=$ yes; $0=$ no \\
Distributors: other local/regional firms & $1=$ yes; $0=$ no \\
Distributors: national firms & $1=$ yes; $0=$ no \\
Distributors: EU firms & $1=$ yes; $0=$ no \\
Distributors: international & $1=$ yes; $0=$ no \\
Customers: local/regional market & $1=$ yes; $0=$ no \\
Customers: national market & $1=$ yes; $0=$ no \\
Customers: EU market & $1=$ yes; $0=$ no \\
Customers: international market & $1=$ yes; $0=$ no \\
\hline
\end{tabular}




\section{Appendix 3}

Description of database variables for competitive strategies

\begin{tabular}{ll}
\hline Description & Codification \\
\hline Investment strategies & \\
Firm invested in: new plant and equipment? & $1=$ yes; $0=$ no \\
Firm invested in: information technology? & $1=$ yes; $0=$ no \\
Firm invested in: the purchase of patents and licensing? & $1=$ yes; $0=$ no \\
Firm invested in: the development of existing products? & $1=$ yes; $0=$ no \\
Firm invested in: the development of new products? & $1=$ yes; $0=$ no \\
Technological strategies & \\
Production process is customised/standardised & $1=$ yes; $0=$ no \\
Technologies adopted: inventory control & $1=$ yes; $0=$ no \\
Technologies adopted: production process technology & $1=$ yes; $0=$ no \\
Technologies adopted: product design technology & $1=$ yes; $0=$ no \\
Technologies adopted: marketing technology & $1=$ yes; $0=$ no \\
Technologies adopted: website/internet & $1=$ yes; $0=$ no \\
Technologies adopted: business to business electronic networks & $1=$ yes; $0=$ no \\
\hline
\end{tabular}

